\title{
STRATEGIC STRUCTURE PLANS FOR PELIYAGODA, JA-ELA AND WATTALA
}

Local Planning Studio 2012 of 2008/2012 Undergraduate Batch

Department of Town \& Country Planning, University of Moratuwa

Reported by Shalini Mariyathas

\section{Introduction}

The strategic structure plans for Peliyagoda, Wattala and Ja-Ela come at an opportune time when the urban development process in Sri Lanka is expanding into every city, town, village and even at each node through various development projects. However, it has been an argument that the kind of urban development that is being undertaken presently results many negative impacts and its outcomes are not favourable as they do not meaningfully incorporate the sitespecific issues. These three development plans reconcile such issues by carefully identifying the root causes of the spatial issues and planning failures if not otherwise addressed. During the period of November 2011 - January 2012, the final year undergraduate students of the Department of Town Country Planning involved in a studio project to prepare strategic structure plans for Peliyagoda, Wattala and Ja-Ela which are competing with each other, having so many potentials not only in terms of resources but also in terms of location.

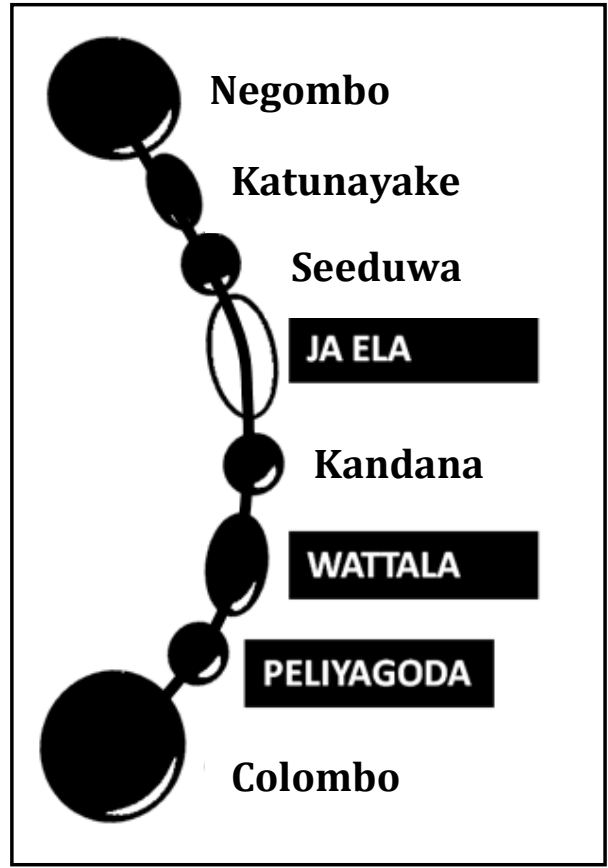

Figure 1: The Three Towns on A3 Belt

\section{PELIYAGODA STRATEGIC STRUCTURE PLAN}

\section{What is Peliyagoda?}

One of the key elements that draw the image of Peliyagoda is Kelani River. Kelani River defines Peliyagoda, adds aesthetic and pleasing value to Peliyagoda, and acts as the natural landmark to Peliyagoda. Thus, the Kelani River is ultimately considered as the Southern and Eastern boundary of the project region. With the population of approx. 30,000 Peliyagoda currently acts as an industrial capital of the country.

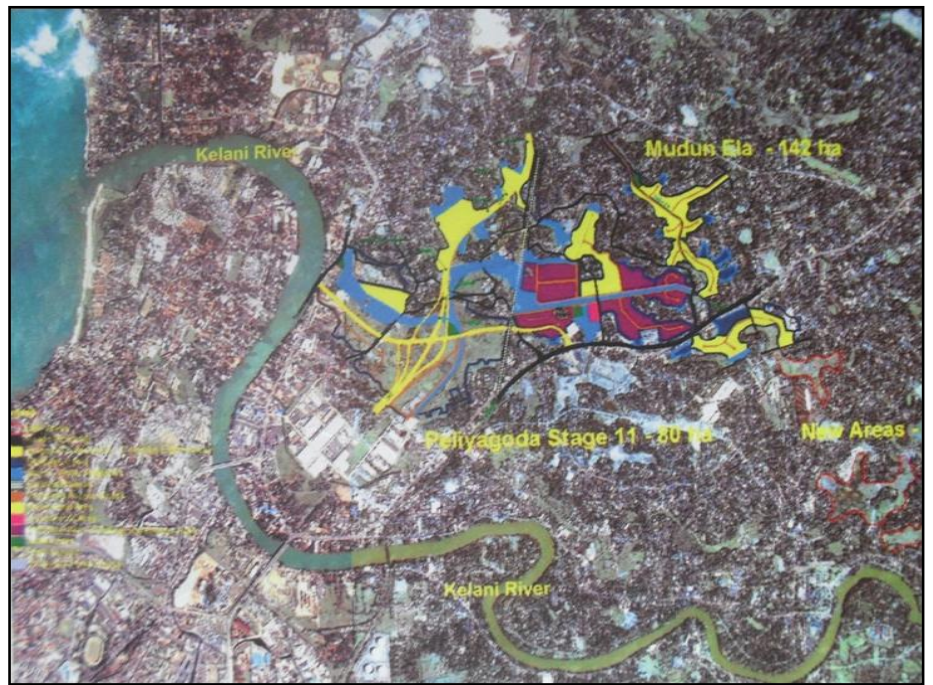

Figure 2: The Physical Setting of Peliyagoda 


\section{Urban Situation Analysis}

Since the plan-making adopted Strategic Planning approach, the careful study of the present situation of the town was an important phase. The present situation is analyzed as part of the Urban Situation Analysis of the planning process. The Urban Situational Analysis is composed of understanding the evolution of space of Peliyagoda, reviewing the previous development plans and policies that impacted Peliyagoda, understanding the spatial form of the town and identifying the key issues and challenges in the present town and the root causes of those issues which needs to be immediately worked out through the proposed plan. The Urban Situation Analysis brought out many facts that are very important for deciding a strategic development direction for Peliyagoda.

The way the early settlers used Kelani River and adjoining marshy areas indicated that filling of these sensitive land covers is the major reason for why certain present issues are existing in Peliyagoda. In other words, the way Peliyagoda has grown so far is not complying with what needs to be conserved and how it needs to be used. Meanwhile, in the present days, Peliyagoda has become a town that is having high political interest in terms of development. Due to the present character of Peliyagoda as a town that is fully occupied by industries and warehouses, the national, regional and

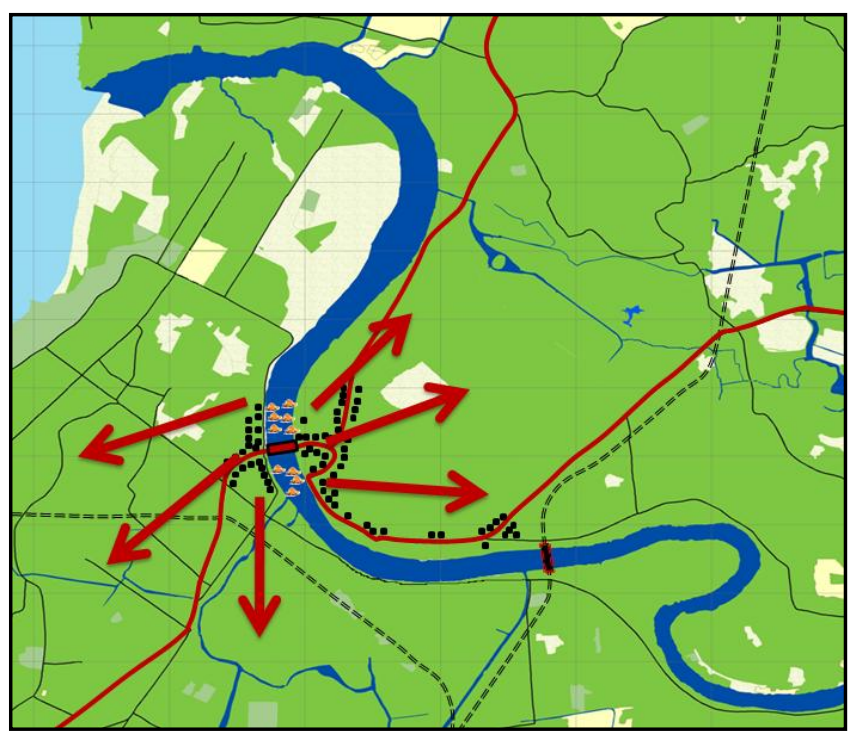

Figure 3: Physical Growth of Peliyagoda

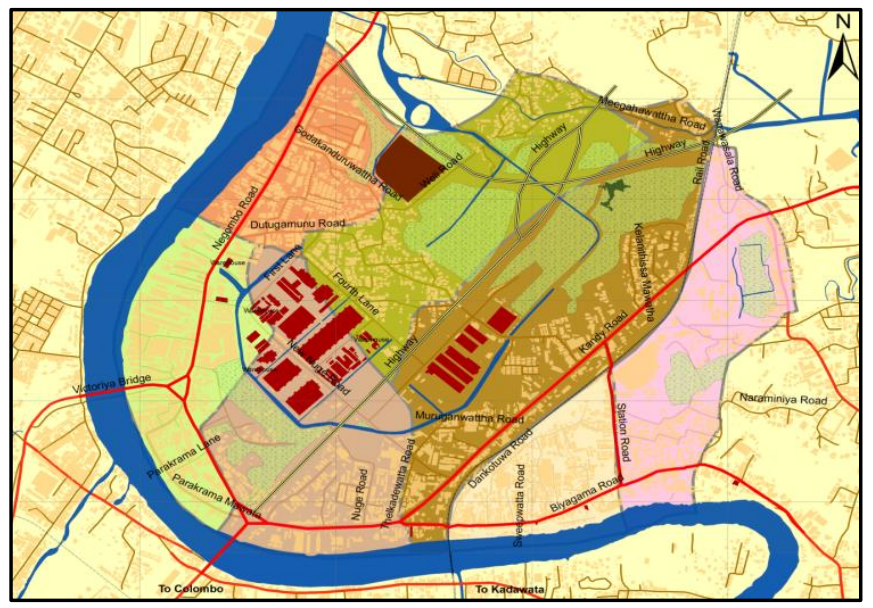

Figure 4: The Present Setting of Peliyagoda

local development plans prepared by government and other planning agencies have targeted Peliyagoda to be an industrial logistic hub, an urban service center, and a metro region with high end development.
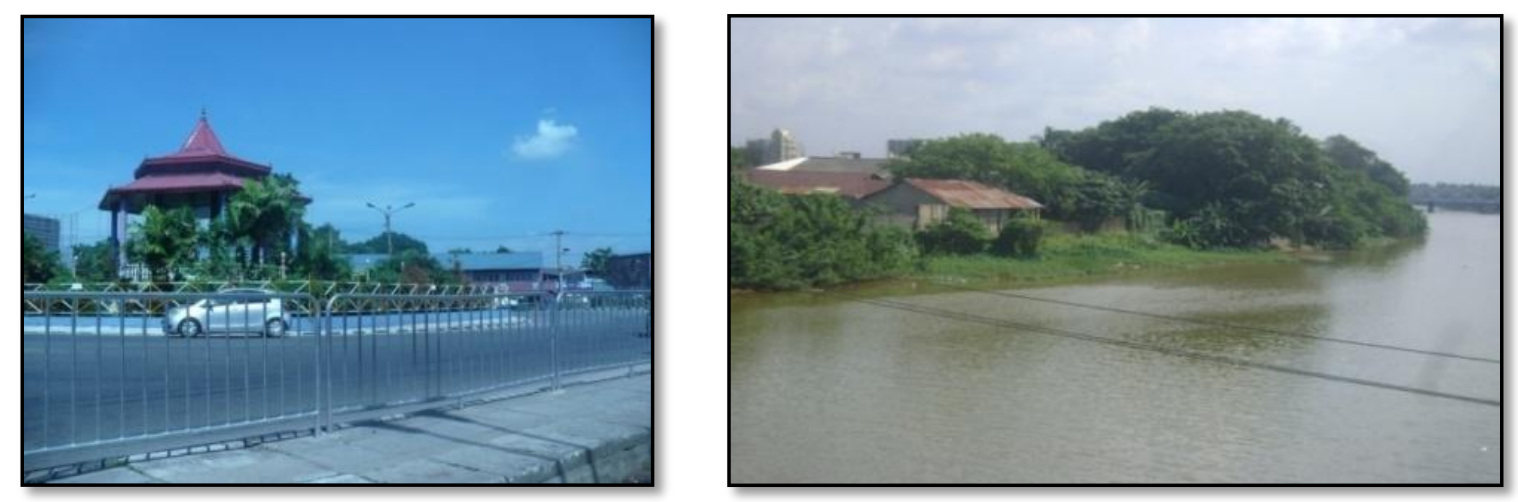

Figure 5: Images of the Physical Settings of Peliyagoda Town 


\section{The Strategic Vision, Goals and Objectives}

The desirable development direction was decided from the alternative development scenarios. This helped to articulate certain principles through which the strategic vision should be derived. The principles were to keep the town multi-functional, high end, eco-people-friendly and accessible. Ultimately, the strategic vision was "The Magnetic Oasis". The vision also had goals and objectives as means to achieve the vision. More importantly, a detail SWOT analysis was carried out to diagnose what are the strengths and opportunities in the town and it's region that can influence on achieving the vision, also what are the weaknesses and threats that need to be approached properly as Peliyagoda moves on to the future.

\section{Strategic Directions}

For Peliyagoda to become the Magnetic Oasis in year 2020, certain strategic directions are proposed that utilize the potentials and resolve the burning issues.

The strategic directions are:

1. Promote catalytic spatial structure

2. Ensure sustainable urban land use management

3. Create elegant contact development

4. Develop as a national economic hub

5. Make sustainable neighborhoods

6. Promote the city as an attractive international destination

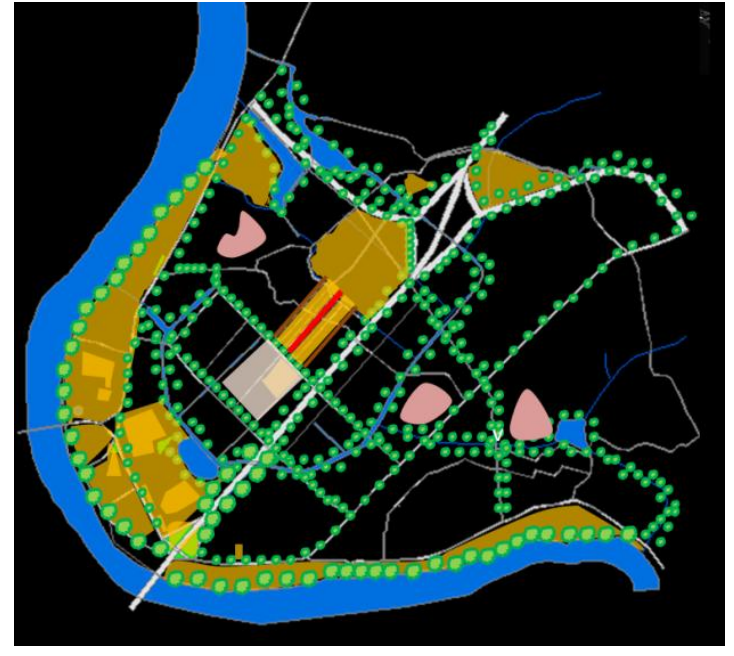

Figure 6: Proposed Spatial Structure

\section{Plans within the Plan}

The strategies need to be specific and focused as well as need to cover the entire Peliyagoda. This concern required the preparation of various sub plans as part of the Strategic Structure Plan. The sub plans prepared were physical structure plan, economic development plan, environmental management plan, settlement development plan, infrastructure development plan and implementation plan.

\section{$\underline{\text { 1. Physical Structure Plan }}$}

A shift from the existing linear form of city structure to nodal spatial form was proposed for Peliyagoda as a means to promote the catalytic spatial structure.
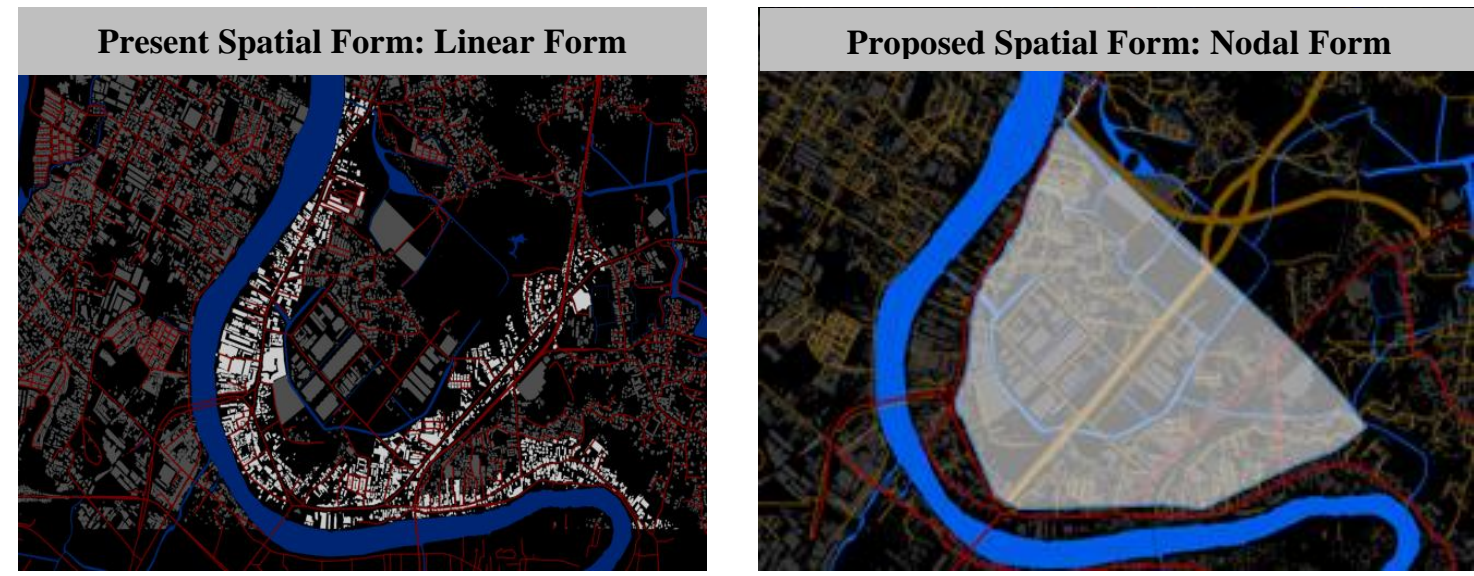

Figure 7: Proposed Spatial Form 


\section{Infrastructure Development Plan}

The primary objective of the Infrastructure Development Plan is to ensure the multimodal, green and smart transportation in Peliyagoda.

The actions taken to provide infrastructure for multi-modal transportation requirements are:

1. Establishment of bus transit terminal (with "park and ride" center for automobile users)

2. Connect the missing linkages and achieve road capacity, and provide necessary street signs, signals and street lights

3. Upgrade multimodal transportation (Air taxi provision, bicycle lanes, train service, roads and streets, highways, three-wheel lanes, etc)

4. Increase greenery and use of street furniture

5. Establish proper regulation system for transit network of Peliyagoda and appoint a Monitoring Committee

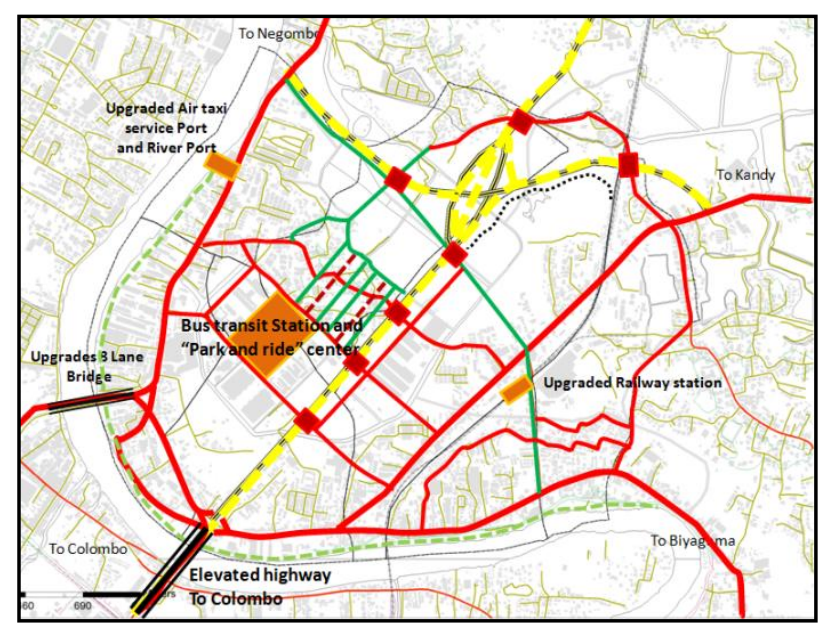

Figure 8: Proposed Infrastructure Development

\section{Environmental Management Plan}

Peliyagoda is richly blue and green having the Kelani River and marshes around. This will be considered as a potential to attract international tourists and business communities to visit Peliyagoda. The primary objectives of the Environmental Management Plan are to establish water transportation for recreational purpose using Kelani River and internal canal network, to promote waterfront development along existing water bodies, to establish high-end shopping centers and hotels to attract high income community to Peliyagoda, and to introduce an integrated solid waste management system to reduce the harmful environmental impacts.

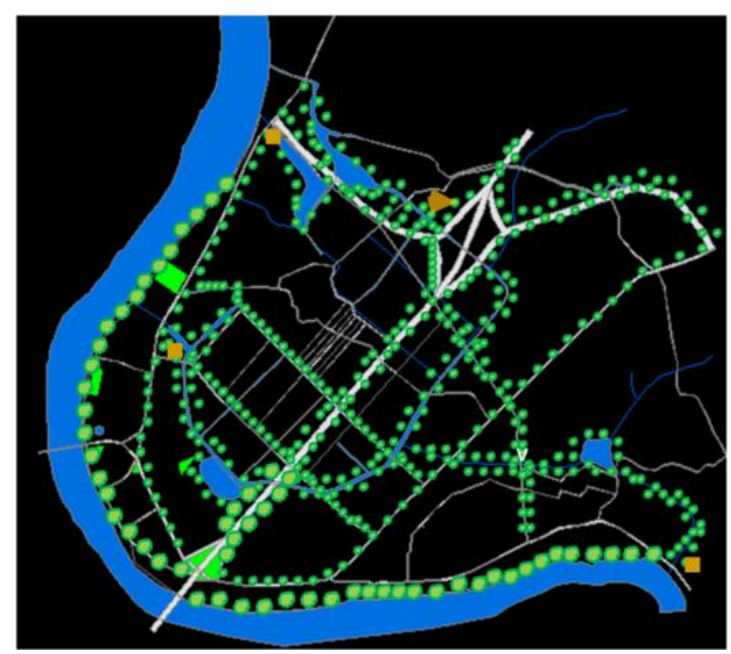

Figure 9: Proposed Green Layout

There are three strategies proposed to achieve the environmental use and protection of Peliyagoda:

1. Improve the green paths and areas to promote a green network

- ACTIONS

i. Removing of industries that are occupying in Sapugaskanda and Biyagama areas.

ii. Removing of settlements in Pattiya East, Pattiya North and Meegahawaththa

iii. Landscaping Kelani River reservation (creating jogging paths and bicycle paths)

iv. Landscaping Peliyagoda junction and Nawaloka Junction area 
2. Mitigation mechanisms for flood that is caused by both river and the canal network

\section{- ACTIONS}

i. Establish flood protection wall along the Kelani River bank

ii. Introduce rainwater harvesting system

iii. Introduce permeable paving to decrease the runoff rate

iv. Widen the canals and increase the capacity.

v. Establishment of storm water retention ponds with

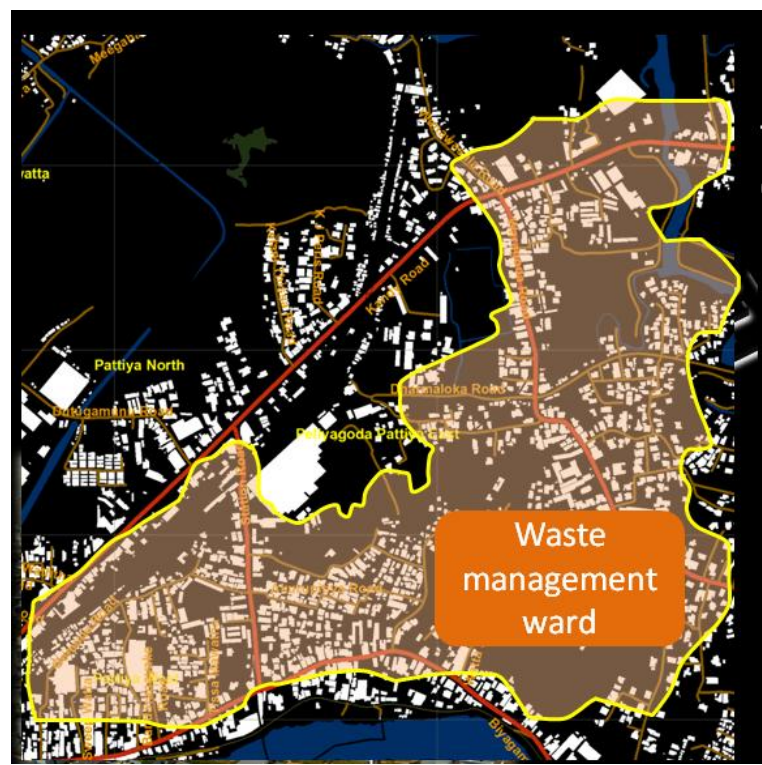

Figure 10: Proposed Solid Waste Management System recharge wells

vi. Build two additional pump stations in Peliyagoda.

3. Introduce an Integrated Solid Waste Management System

- ACTIONS

i. Application of waste management cells to optimize the waste collection mechanism

ii. Optimize the solid waste management and collection mechanism

iii. Optimize solid waste transport mechanism

iv. Enhance the economic value of solid waste.

v. Solid waste management plan

\section{Settlement Development Plan}

It is found that $51 \%$ of the Peliyagoda residents are under low income category. Therefore, this plan aims at proposing sustainable neighbourhoods. The primary objectives are providing adequate housing for 4,630 families by year 2025 and promoting vocational training to create skilful community in Peliyagoda. These identified 4,630 families are currently occupying along the Kelani River reservations, Canal reservations and railway reservations. Under this

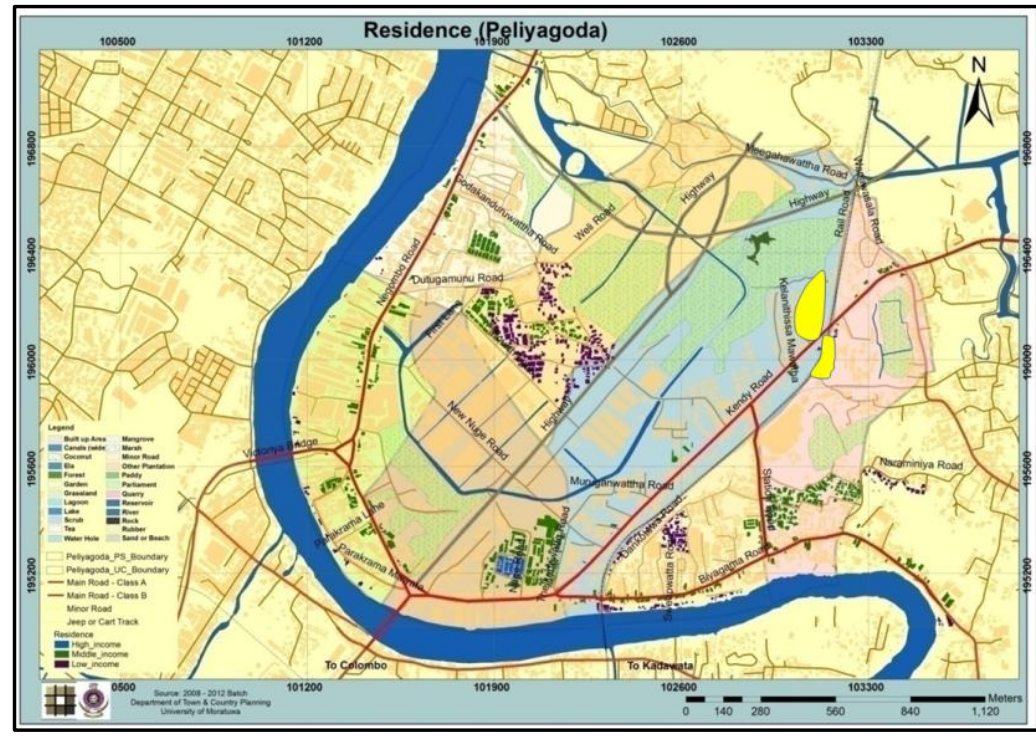

Figure 11: Proposed Settlement Development Plan 
plan, three resettlement projects were identified with the aim of providing adequate infrastructure facilities and adopting voluntary resettlements concept.

\section{$\underline{\text { 6. Implementation Plan }}$}

In order to reach the vision of the plan in year 2025, various aspects that are proposed in this plan need to be monitored and managed by professionals and experts. These functions cannot happen at the Local Authority level due to lack of capacity in terms of financial and human resources. The project team proposes the establishment of Peliyagoda Development Organization (PDO) under the provisions of Urban Development Authority Act No 41 of 1978. The PDO will have a Board of Directors that comprised of Chairman UDA, two representatives of UDA, Peliyagoda housing market representatives and warehouse sector representatives.

\section{JA-ELA STRATEGIC STRUCTURE PLAN}

\section{What is Ja-Ela?}

Ja-Ela is one of the highly urbanized cities in the Gampaha district. It is located at a nodal point at the intersection of A33 road and Ekala-Gamapha road. This node is targeted by the intersection of Katunayake-Colombo expressway as a major focal point for future development. Ja-Ela town consists of two administrative regions such as Ja-Ela Urban Council area and Ja-Ela Pradeshiya Sabha. However, the functional boundary of the Ja-Ela town goes beyond the administrative boundary of the town. Ja-Ela area is consolidated with the adjacent areas Kandana and Ragama in the South and merging with Ekala in its East.

Ja-Ela is located proximity to Colombo National Commercial hub with minimum distance to reside, work, leisure and pleasure. It is highly connected to the outer national, regional and local centres. Further, Ja-Ela city is the geographical core of South West Metropolitan, situated along the A3 main road, proximity to the Colombo-Chilaw railway and a railway station at center and connecting to the main rail transition at Ragama, near Katunayake.The nodal potentials and the arrival of highways, along with all the advantages that the location of Ja-Ela brings, the city has unique value comparing to other cities in the region.

\begin{tabular}{|c|c|c|c|}
\hline & $\begin{array}{c}\text { Divisional Secretariat } \\
\text { Division }\end{array}$ & Urban Council & Pradeshiya Sabha \\
\hline $\begin{array}{c}\text { Land Area } \\
\text { (sq.km) }\end{array}$ & 58.94 sq.km & 7.7 sq.km & 55.44 sq.km \\
\hline Population & 227,801 (Yr 2004) & 35,734 (Yr 2011) & $185,562($ Yr 2005) \\
\hline
\end{tabular}

\section{Urban Situation Analysis}

The present situation analysis is carried out through location analysis, evolution of space, town formation, present role of the town, land form, spatial form, socio-spatial form, key challenges, issues and problems of the area, and national and regional policy context.

\section{i. Evolution of Space}

The significant change occurred in Ja-Ela during the Dutch era (1656), with the construction of Ja-Ela canal. It was constructed by expanding Uruwel Oya up to Negombo lagoon. The Java communities who brought to Sri Lanka by Dutch used as labors during the construction of Ja-Ela 
canal. This is how the city got its name - Ja-Ela. The city evolution shows the tremendous growth and land use transformations after the establishment of Katunayake Export Processing Zone (EPZ) and Bandaranayake International Air port in 1970s. The Katunayake EPZ attracted large number of new comers to the city by providing more jobs. The land use maps of different periods show that there was a significant increase in the residential uses. Ja-Ela residents began to rent out their houses and rooms for new comers and this turned out to be a major income source for Ja-Ela residents. Further, hotels and lodges started to spread in Ja-Ela in order to cater the increasing demand for temporary accommodation. Thus, the location along the Air port corridor and close to industrial zones made Ja-Ela a prominent city in the Western Province.

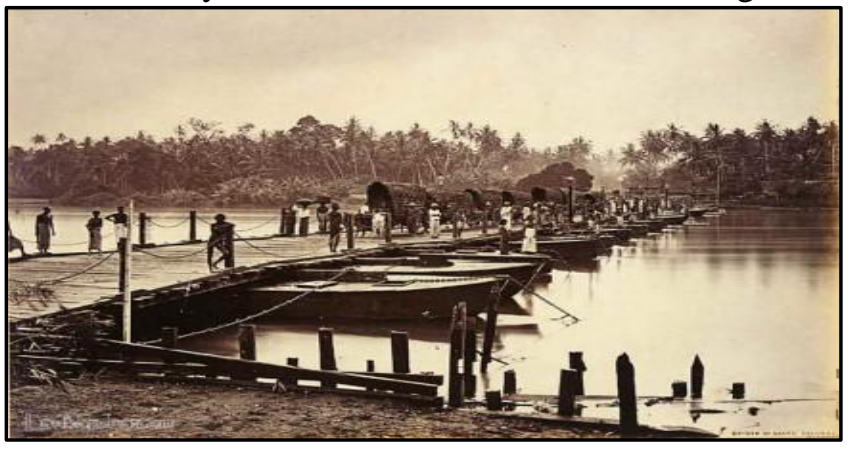

1980s brought another major transformation to the form and character

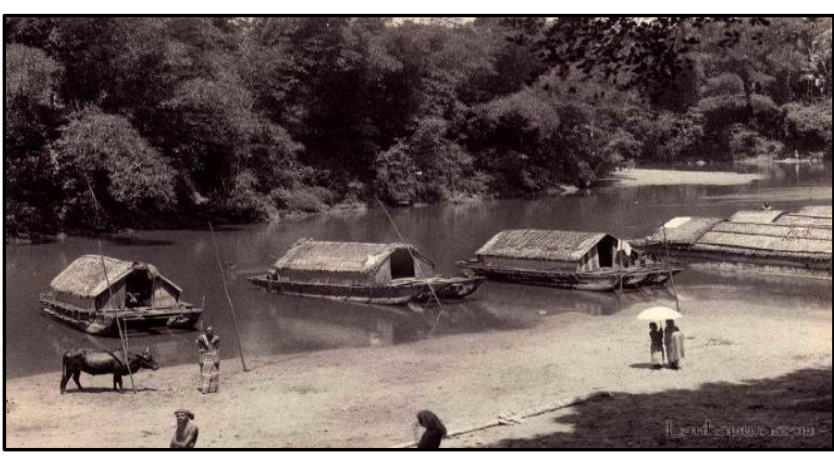

Figure 12: Images of the Evolution of Ja Ela of Ja-Ela due to the Colombo-Puttlam Road (A3) Development Project. There were both positive and negative impacts due to the A3 Road construction. The positive impacts such as the city got the linear form in terms of growth and development, advanced physical infrastructure and improvement as well as the development of tourism industry. The negative impacts identified such as the relocation and demolishment of residences and commercial areas, increasing traffic jam, air pollution and unauthorized constructions.

\section{ii. Policy Review}

The national, regional and local policy plans were reviewed in order to identify the development targets that are already set for JaEla by various planning agencies. The National Physical Plan 2030 suggests Ja-Ela to

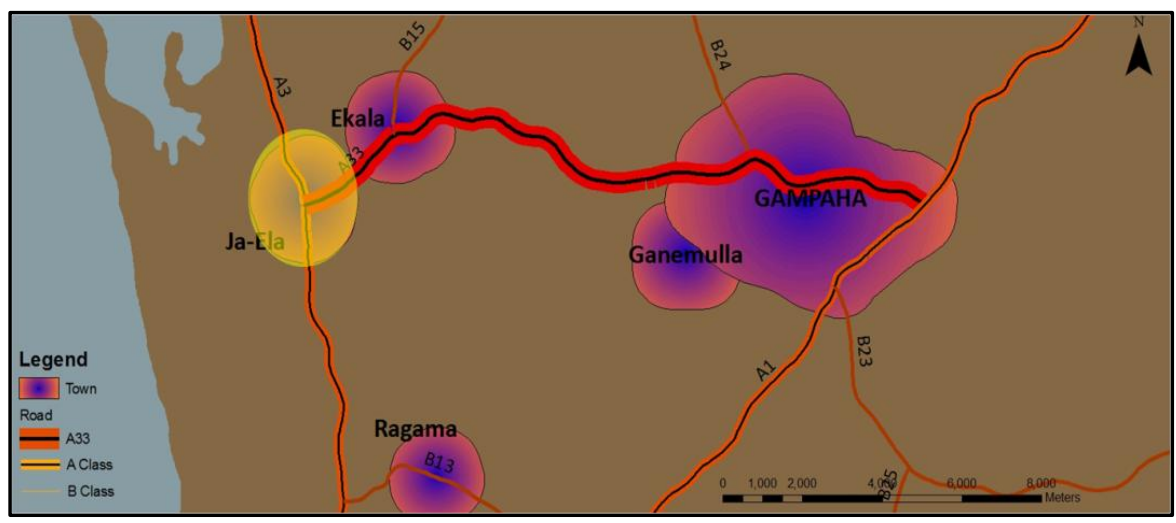

Figure 13: Ja-Ela in its Regional Context act as a residence provider of Western metro region in year 2030. This indicates the potential of Ja-Ela to be a center of accommodation and a center of transport interchange. This plan also has a proposal to rehabilitate the existing road networks and construct regional highways to connect the urban regional centers. Mahinda Chinthanaya 2010 proposes Ja-Ela and Gampaha towns to be developed as environment friendly modern cities to attract middle income communities while acting as major commercial hubs in South Asia. According to the 3-K proposals, Ja-Ela is connected to the Outer Circular Highway through Katunayake- Colombo Expressway. Majority of 
the benefits of the connection to major highways are planned to go to the locals of Ja-Ela. The interchange that is proposed to be in Ja-Ela will also be a potential.

\section{City Evolution}
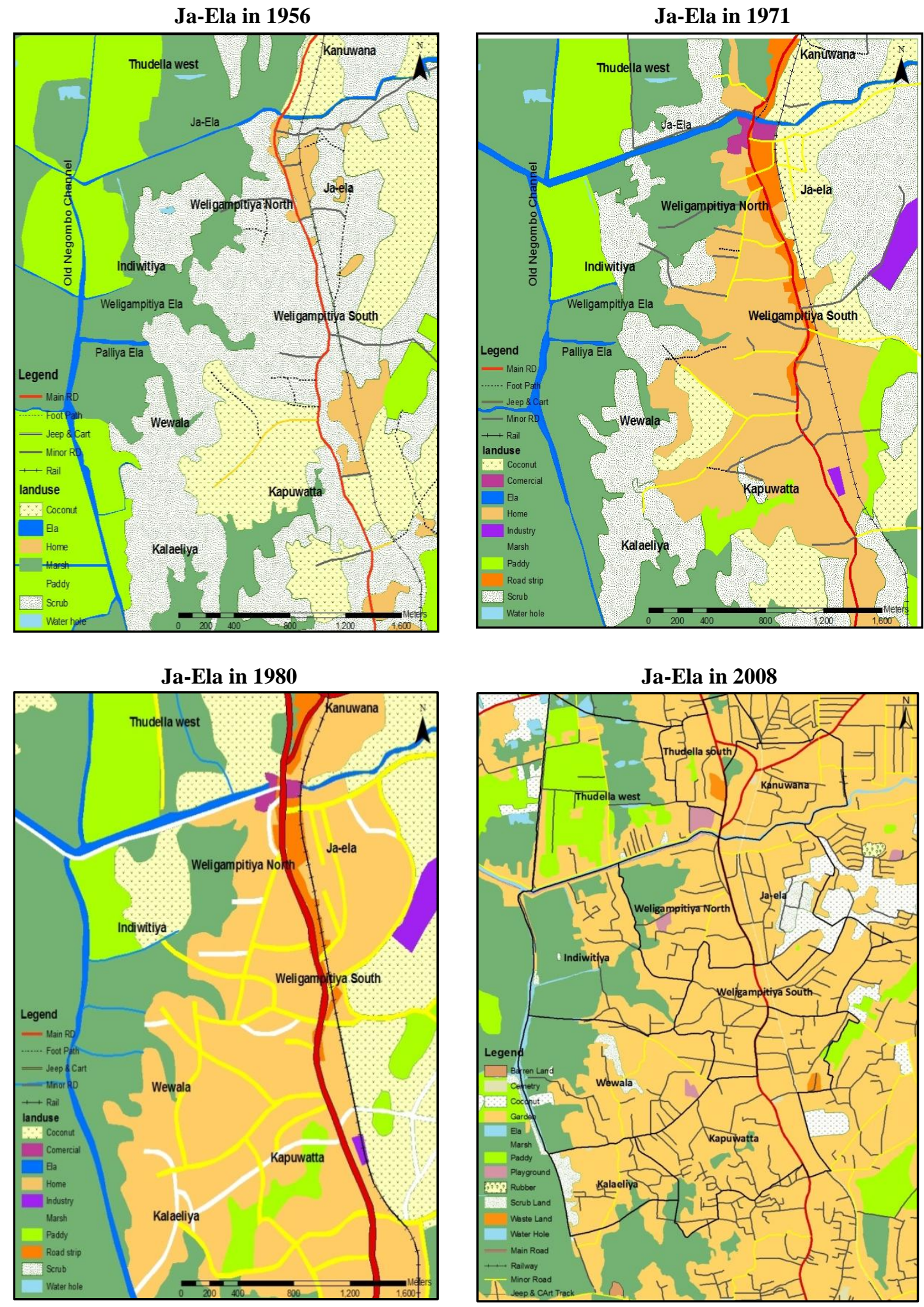

Figure 14: Transformation of the City in Different Periods 


\section{v. Key Issues and Challenges}

- Backyard of Ja-Ela with major issues The west side edge of Ja-Ela is covered by marshes and wetlands, also has small settlements such as Wewala West, Indiwitiya, Suduwella, Thudella West, Kanuwana, and Kala Eliya. These settlements are identified as socially excluded, economically weak and exposure to flash floods. There are about 8300 families living in these settlements in temporary dwellings with poor facilities.

- Immature business and service sectors The existing commercial and service sectors of Ja-Ela are inadequate to cater the demands and needs that are already reached high level. This is caused by the sluggish local economic development, inadequate infrastructure in the town, and limited means of financing.

\section{- Exposure to flash floods}

During the rainy seasons, the main streams

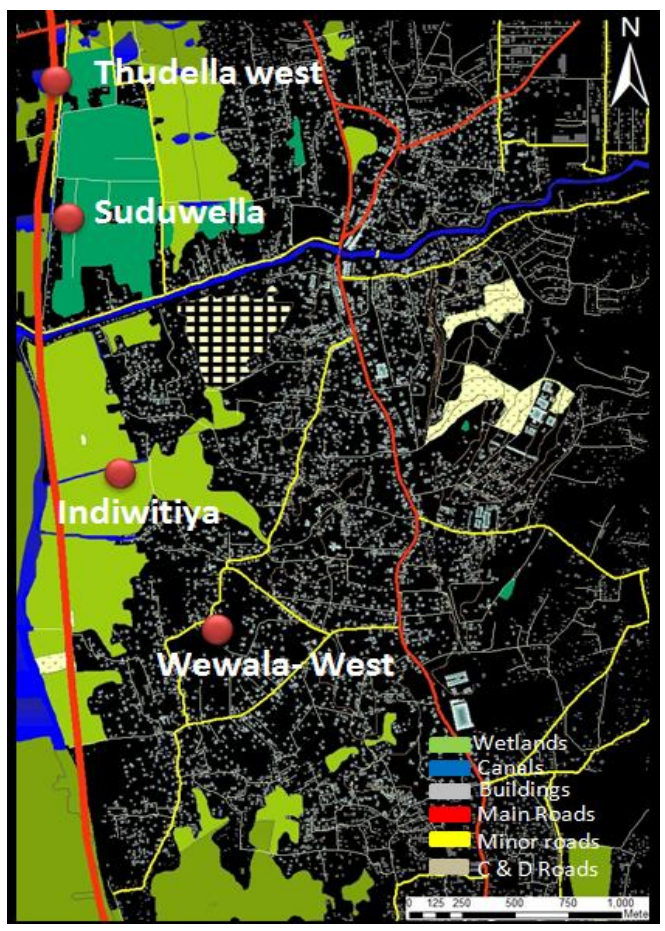

Figure 15: The Backyard of Ja-Ela such as Attangalu Oya,Uruwal Oya, Dadugam Oya and Ja Ela are over flowing and causing flash floods. Further, lack of storm water drainage system for draining storm water runoff to the main streams or Muthurajawela also a major cause for flooding in the city.

- Ground water pollution and salt water intrusion in certain areas

Mercury and human excrete are mixing with ground water and make it un-portable in certain areas such as Vishakawatta, Ekala, Alexsandra watta, and Mahawatta. Salt water intrusion issues are found in Kapuwatta, Daduagama, Thudella, Wawala, and Nagoda.

\section{- Misuse of urban marsh}

Certain parts of Muturajawela marsh is used for garbage dumping by the adjoining settlements. Due to this, the marsh land blocks the natural drainage system, causing the vector born diseases and the entire marsh area has become a vulnerable site.

- Unplanned and Unauthorized Land Filling

The unauthorized land filling for temporary dwellings has broken the natural drainage network, decreased the water retention area, increased the flood level and caused the loss of habitat for fauna flora species.

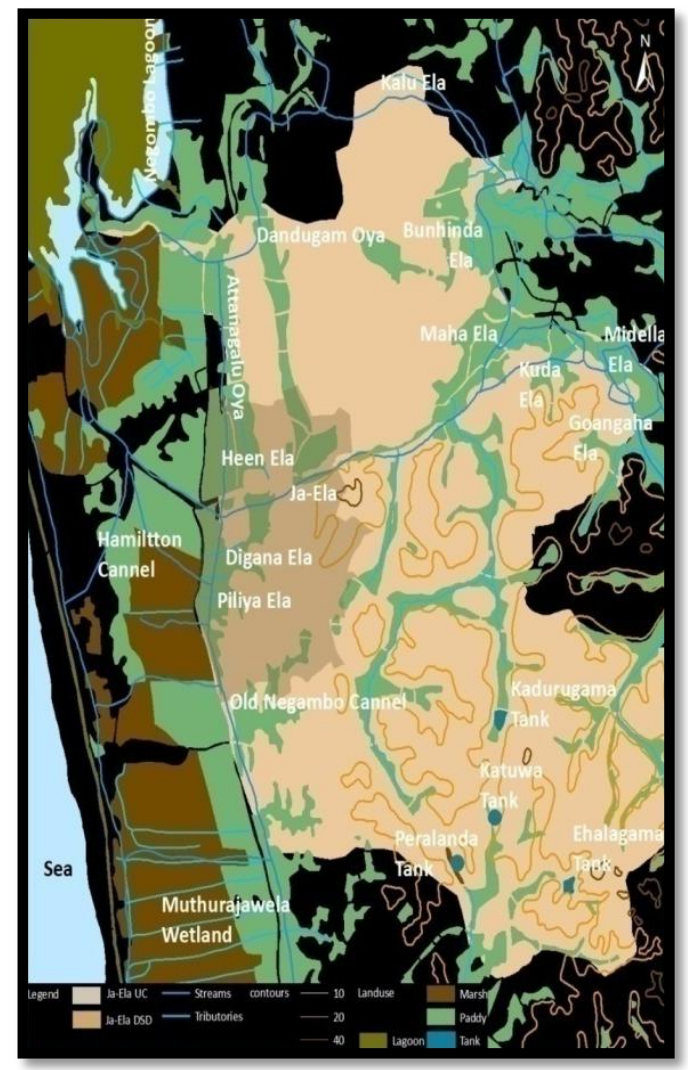

Figure 16: Flood Prone Areas 
- Isolated large scale developments distort the townscape of Ja-Ela

The increasing job opportunities and increasing new comers have led to the development of luxury housing schemes in and around Ja-Ela. This rapid development of the high class residential areas excludes the lower spheres of the local community. Further, these high class communities are making every effort to sustain separately in the townscape.

- Other issues and challenges:

- Poor accessibility

Spatial distribution of road network is less than the normal standard coverage for roads. Roads are $4.92 \%$ out of total land uses. Land allocation for roads in urban area is $18 \%-20 \%$ of total land coverage.

- Unequal distribution of public transportation creates low accessible zones in the Westside of the city.

- Absence of pedestrian friendly walkways creates less comfort, time consuming journeys.

- Traffic congestion at main road [main node].

\section{The Strategic Vision}

\section{"Dynamic Business Hub with Luxury Living: Node of Trade, Home \& Enjoyment"}

The vision calls Ja-Ela to be a liveable city of trade and entertainment. This city presents a unique opportunity for collaboration between public and private entities to create an integrated mixed-use urban destination. It is envisioned to be a place to live, work, learn, play and visit. This should be a sub regional center with a wide variety of employment, recreational \& entertainment venues for everyone, blend of nature, open spaces and water, express the sustainable development that enhances the connectivity to other key locations in and around the city.

\section{Strategic Directions, Goals and Objectives}

In order to achieve the strategic vision, this plan proposes five strategic directions for Ja-Ela and each direction has goals and desired ends.

1. Ja-Ela as a vibrant economic destination

Goal:

Promote a vibrant, diversified economy that enhances the quality of services while maintaining a competitive tax rate.

Desired Ends:

- Creating business core targeting regional businesses such as luxury goods and services distribution centre for region;

- Developing Eco-destination centre that serving to tourists and visitors which pass Ja-Ela from Katunayake and Colombo;

- Pedestrian friendly activity centres connected by alternative transportation modes and trails;

- Providing diverse employment opportunities to local people.

2. Ja-Ela as a safe and comfort city with green on blue

\section{Goal:}

Preserve and enhance a beautiful city that is clean, safe, and aesthetically pleasing; a city that will foster pride and dignity to our citizens, corporate community, and visitors. 


\section{Desired Ends:}

- Flood free and disease free city in the Western Province.

- Provide a network of urban parks that meets the recreation needs of the community.

- Identify and protect open spaces and critical natural areas

- Attractive, well-designed, properly maintained commercial areas, public buildings, streetscapes

- Clean, well-maintained lakes and waterways that are accessible by locals

- Reduce, reuse and recycle for reduction of wastes

3. Ja-Ela as a user friendly access network for higher mobility

Goal:

Convenient, efficient, and safe movement of people and goods while maintaining neighbourhood integrity

Desired Ends:

- Well-designed and maintained streets, sidewalks and multi use roads

- Well connected pedestrian-friendly environment with multi use walkways for bikes and pedestrians

- Design measures for traffic calming for upcoming Highway and regional road intersections

- Pedestrian service places on interior nodes (gathering area, public toilets, seating places)

4. Ja-Ela as a lively neighbourhoods in habitable environment

\section{Goal:}

Provide equal opportunity and encourage participation of all citizens in the economic, social, and civic life of the community within the well designed neighbourhoods

Desired Ends:

- Strong neighbourhood identity and pride

- No socially isolated groups - city is a common space - all family generations and all cultures are welcome to have a pleasurable life style in Ja-Ela

- Maintaining quality neighbourhoods and buffered from or blended with adjacent commercial areas and non-residential land uses

- People feeling secure and comfortable at home, in the neighbourhood, at the parks, in commercial areas, and within the entire community.

5. Ja-Ela as a sustainable land use management for efficiency and compatibility

Goal:

Achieve a balanced and orderly use of land that will preserve and enhance the quality of life within Ja-Ela while developing a diverse and sustainable city Desired Ends:

- Maximize economic benefits of wetlands while keeping environmental value.

- Innovative designs that meet city's development standards and adding value to the surrounding neighbourhoods. 
- Development and redevelopment of buildings incorporating with the concepts of environmental sustainability and consistent with city vision, comprehensive plan, policies and standards.

\section{Re-structuring the City Form}

The Urban Situation Appraisal examined the present form of the city. The natural forces, linear forces and regional forces impact the spatial form of Ja-Ela and the existing linear form of the city is not compatible with the development trends and emerging needs. Therefore, a new spatial form was proposed for Ja-Ela that could reduce the spatial issues, optimize the land area, potentials and resources while supporting the recreational needs.

The present linear form that is created by main road, railway line, Marsh and Ja-Ela Canal is considered as a 'Sheet' - a sheet with lines of roads and waterways. This sheet of Ja-Ela will be transformed as an 'Articulated Sheet' - a sheet that has shapes, designs and colors - by introducing an access network, development of central clusters in the new city core and new city edge and gradual development of specialized sub clusters such as emergence of new neighborhoods, commercial corridors, entertainment areas, etc.

Further, the development concept adopted for Ja-Ela in this plan is 'Core and Edge Concept'. A new city core and new city edge are proposed and needed strategic actions are proposed to revitalize this core and edge.

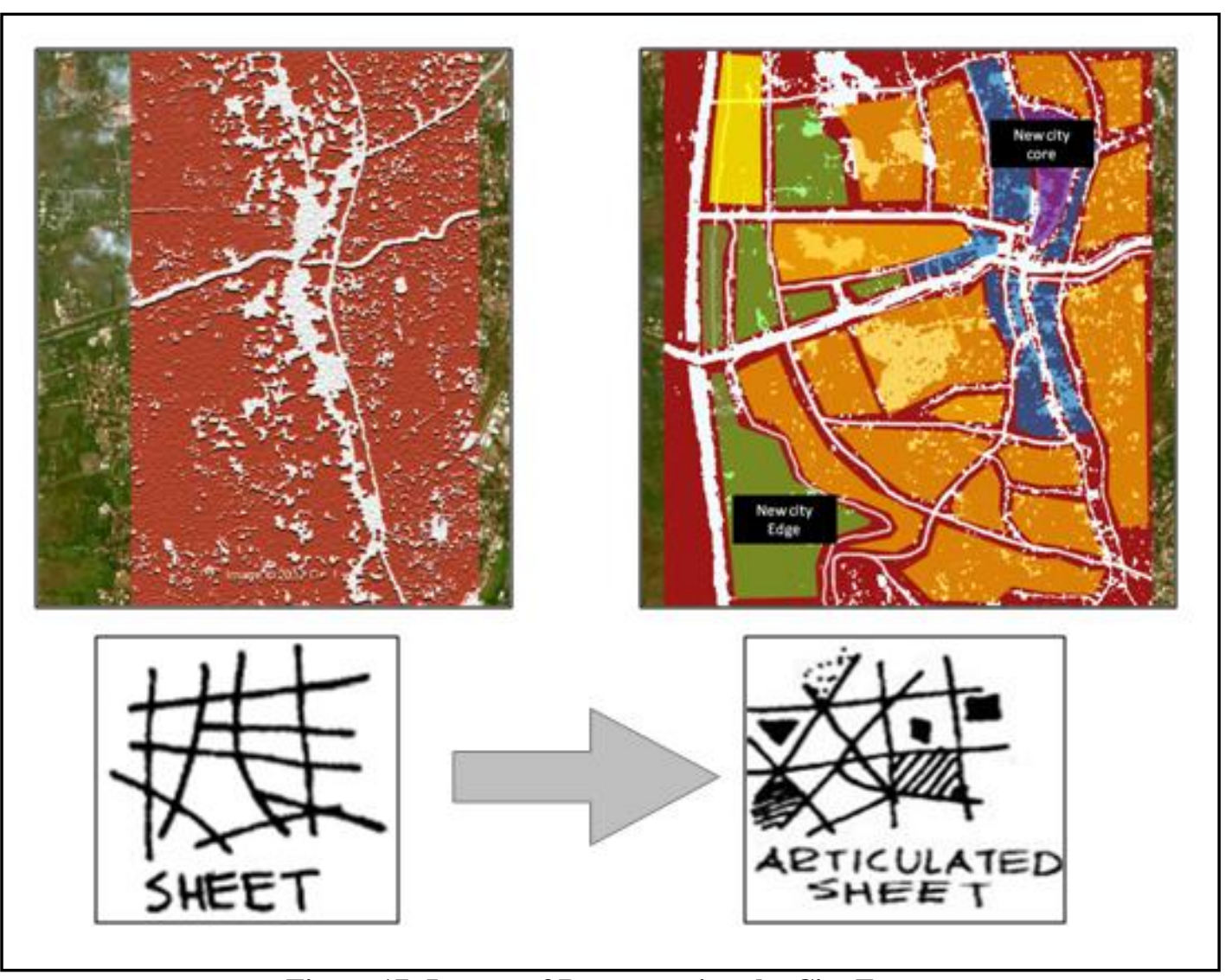

Figure 17: Layout of Restructuring the City Form 


\section{Strategies and Strategic Action Projects}

Strategy 1: Vibrant Economic destination (Through Core \& Edge Development)
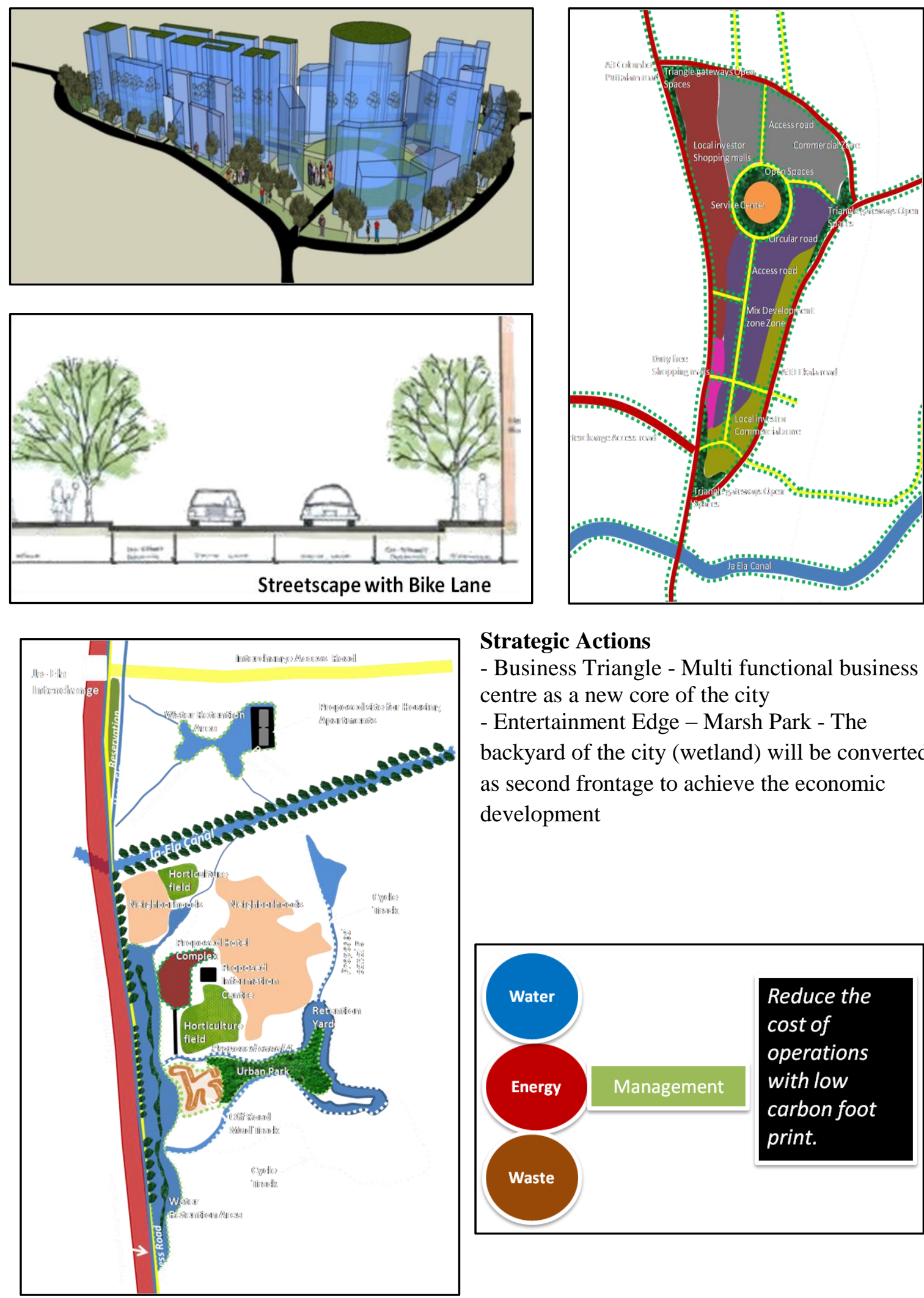

\section{Strategic Actions}

- Business Triangle - Multi functional business centre as a new core of the city

- Entertainment Edge - Marsh Park - The backyard of the city (wetland) will be converted as second frontage to achieve the economic development

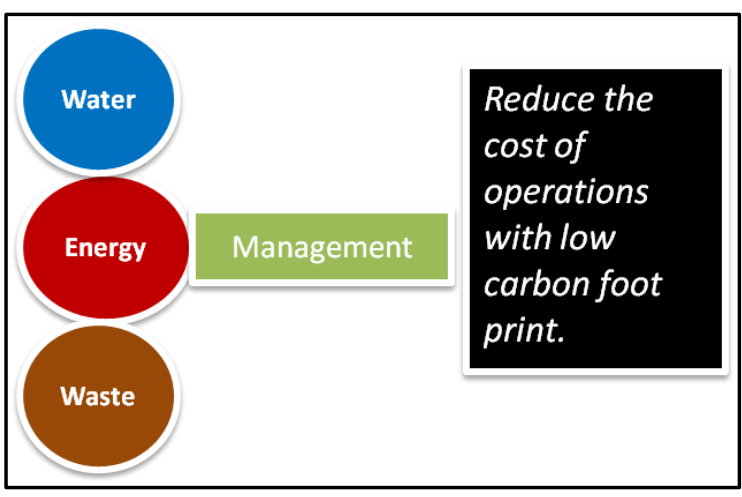

Figure 18: Proposed Business Triangle and Environmental Edge 
Strategy 2: Creating a functionally efficient access network Strategic Actions

- Proposed Traffic plan:

- To reduce traffic congestion in main road \& business triangle, improve the connectivity

- To enhance the accessibility

- Convert interior roads into green streets and give the access to open space \& recreation space.
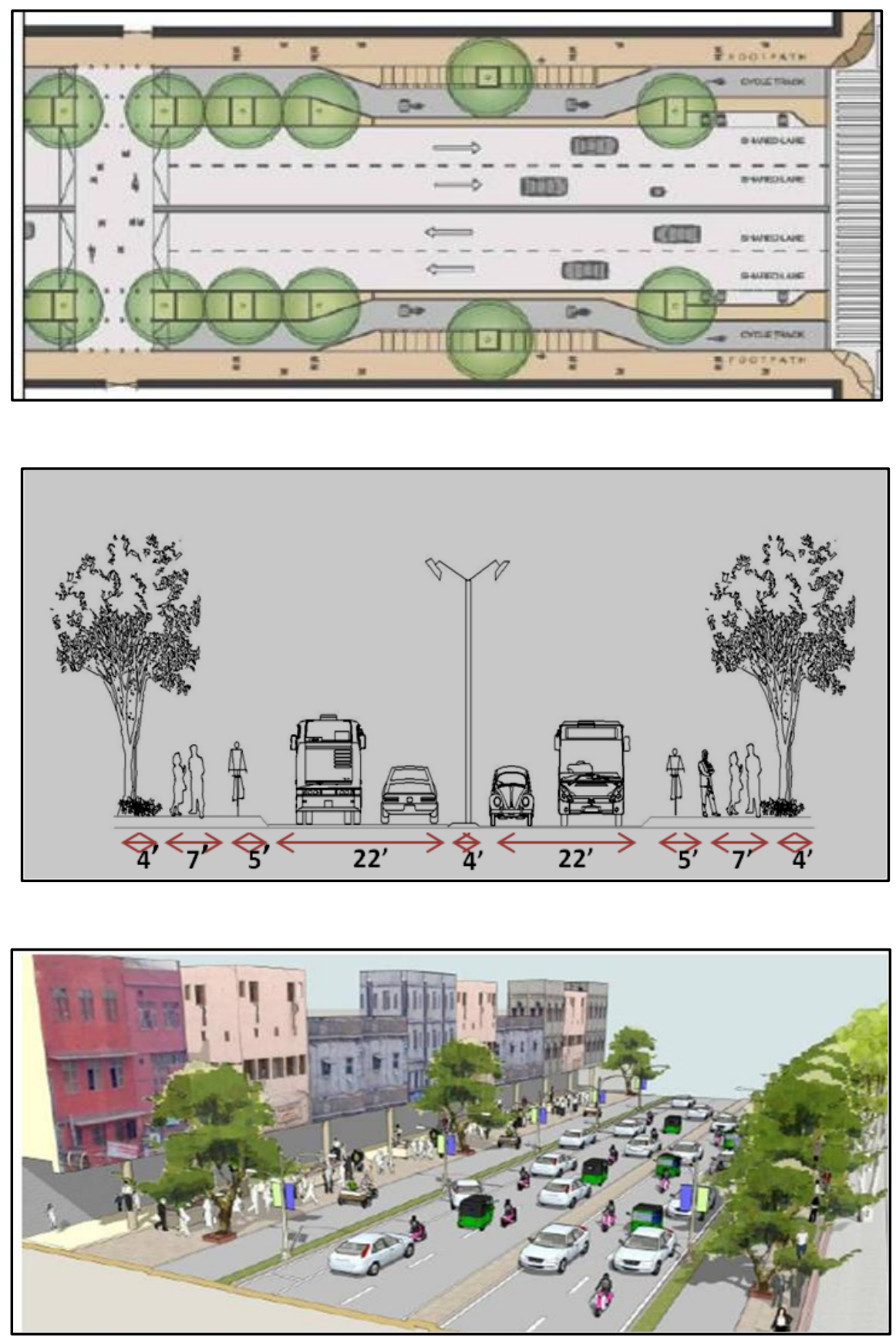

Figure 19: Proposed Efficient Road Network 

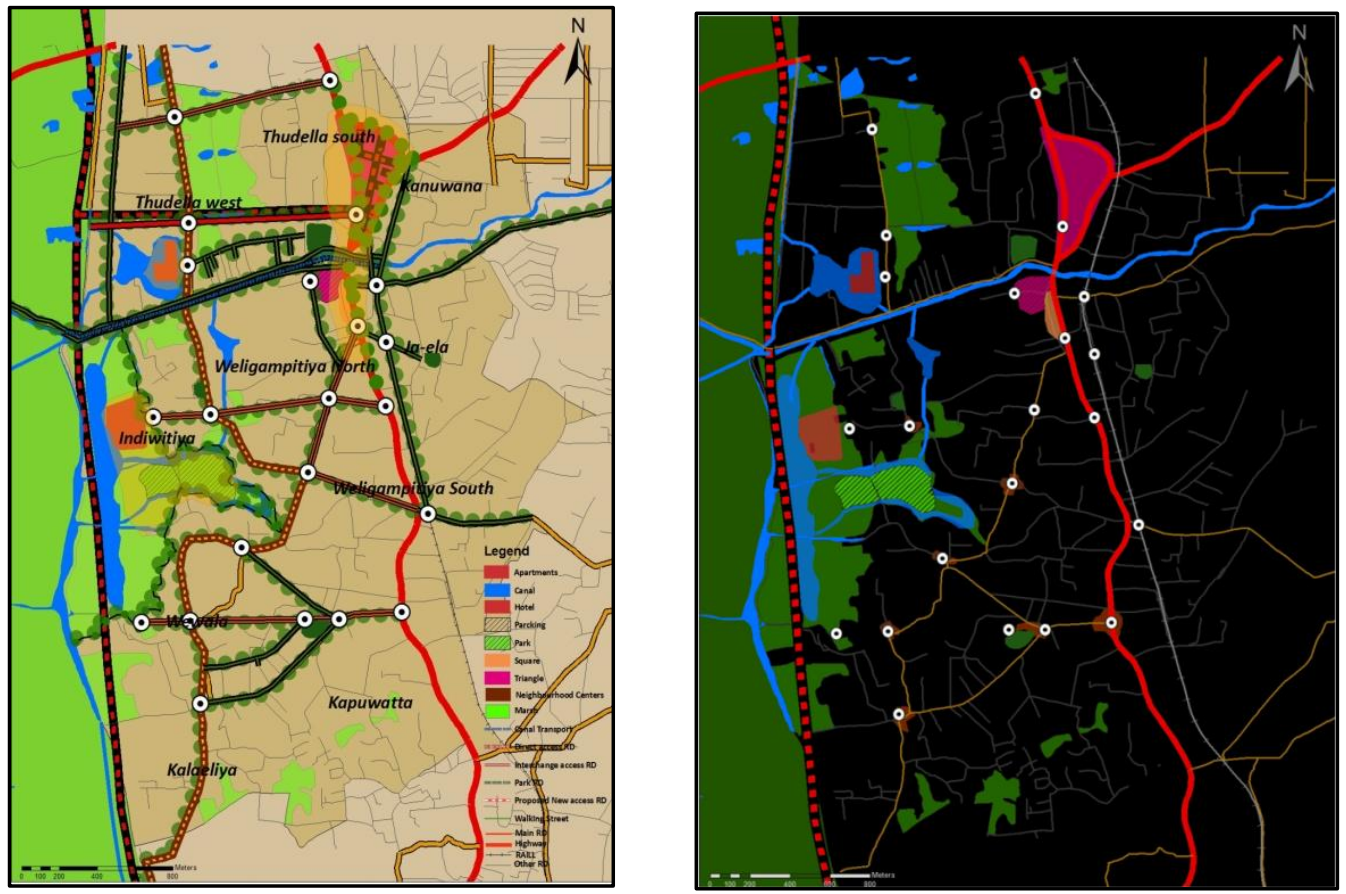

Figure 20: Proposed Environmental Management Plan

\section{Strategy 3: Storm Water Management and Flood Mitigation Strategic Actions}

- Flood mitigation strategies

- Channelization

- Canal Diversions

- Canal re-sectioning (Gabion wall)

- Bank protection

- Dykes/ Embankments

- Vegetation planting/ clearing

Strategy 5: Employing the Unemployed Labor

\section{Strategic Actions}

- Educating the urbanists (improvement of skills of labor through vocational training centre)

- Promote keera cultivation in selected abandoned paddy field

- Promote fresh flower industry in selected abandoned paddy field

\section{Strategy 5: Housing and Human Settlements Development Strategic Actions}

- Facilitating commercial pockets in the centre of neighborhoods

- Providing a public spaces for every selected neighborhoods by surrounding commercial pockets

- Building up a social capital within the neighbourhoods through an organizing mechanism

- Building up a social capital within the neighbourhoods 


\section{WATTALA STRATEGIC STRUCTURE PLAN}

\section{What is Wattala?}

Wattala currently acts as a service node catering the surrounding small towns such as Kelaniya, Peliyagoda, Ragama, Elekanda and Hekitha. Wattala is a linear town center and it's activities concentrate along A3 main road. Wattala substantially contributes to the proposed five hubs of 'Mahinda Chinthana'. Aviation hub of Katunayake international airport, Naval hub of South Colombo port, Wattala as a Commercial hub in its location, Energy hub of Kerawalapitiya thermal power plant and Knowledge hub of Research and Development Center at Muthurajawela Mash.
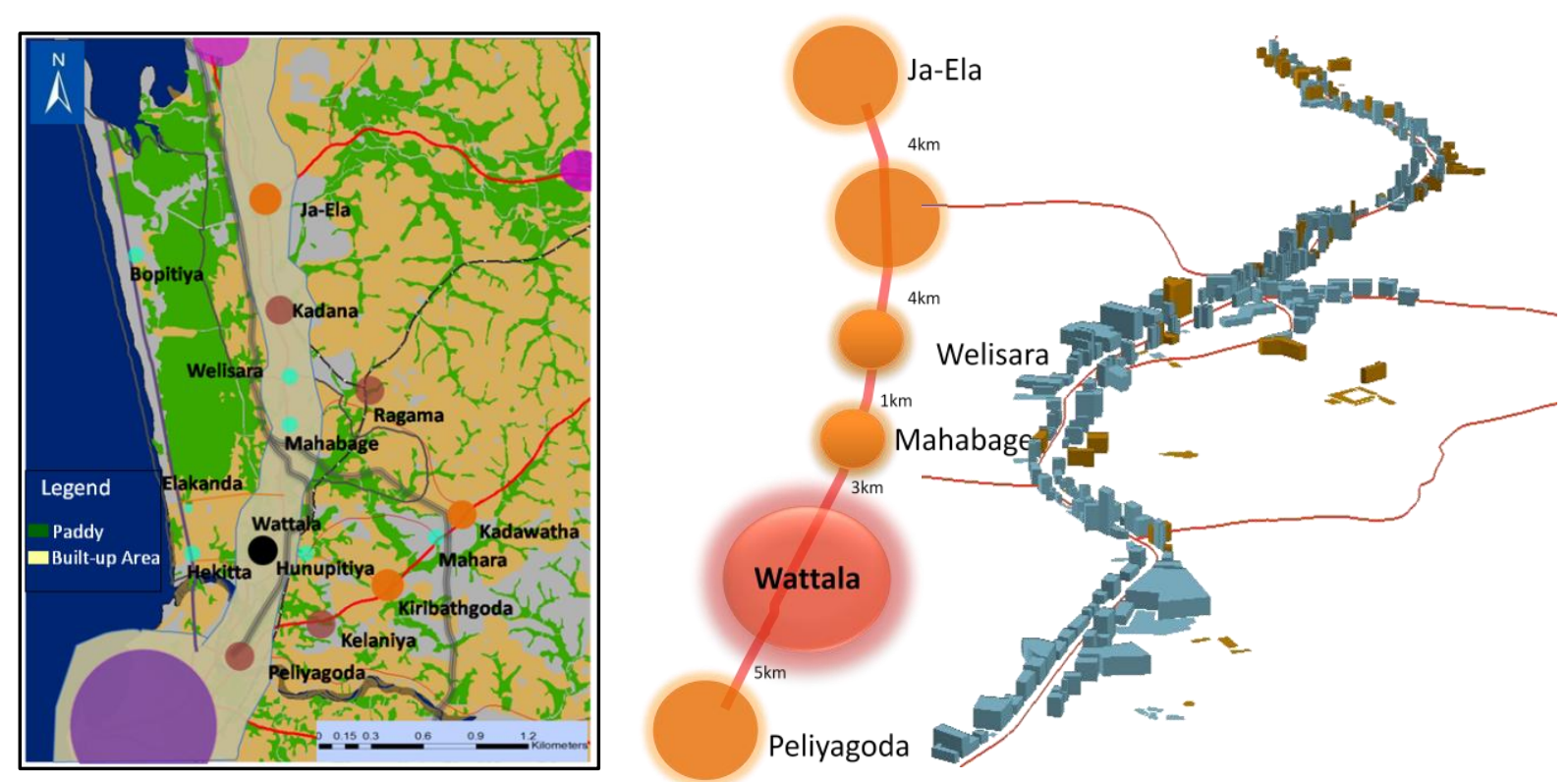

Figure 21: The Location and Existing Form of Wattala

\section{Strategic Vision}

\section{Wattala, the SMART City with Sustainably Developed People Friendly Corridor}

The vision has been formulated based on the below principles:

- Waterfront development

- Economic competitiveness

- Livelihood

- Night life

- People friendly attractive environment

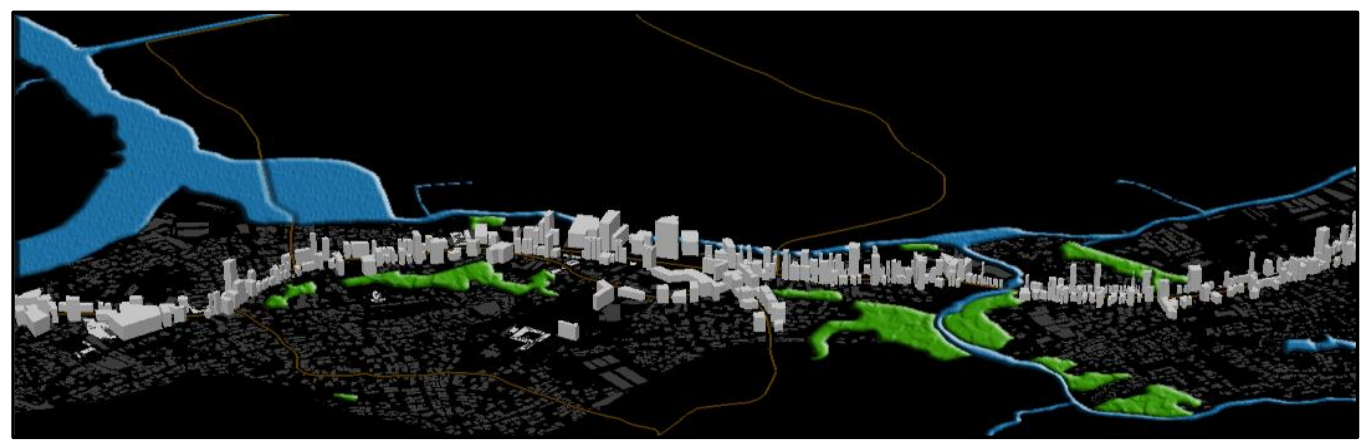

Figure 22: Proposed Spatial Form of Wattala 


\section{Goals and Objectives}

- Goal 01: Developing Wattala as a trade and service center in the Western region.

- Diversifying the trade and service activities of Wattala by 2030 to promote Wattala as a multiple business corridor

$\circ$ Rearranging the trade and service activities to increase the efficiency by year 2030.

- Allocating more prime lands for commercial development by 2030 .

- Goal 02: Increasing the efficiency of mobility with in and around Wattala by developing the existing transportation network.

- Creating a safe and pedestrian friendly environment within the city by 2015 .

- Minimizing the existing traffic congestion within the city by 2030 .

- Creating a efficient and planned transportation network within Wattala and its surrounding cities within three years.

- Goal 03: Creating a secure living environment for Wattala dwellers.

- Creating flood free environment by 2030.

- Creating a waste free environment in Wattala in 2020.

- Constructing a drainage network in Wattala by 2020.

- Constructing public and urban spaces for the wellbeing of the migrants and city dwellers by 2020 .

- Goal 04: Utilizing the unutilized and underutilized resources in the environment in a sustainable manner.

- Constructing recreational spaces by utilizing the existing green network and water bodies by 2020 .

- Maintaining and restoring the cannel network in Wattala within three years.

\section{Spatial Strategy}

The present spatial structure of Wattala was studied using the below criteria:

- Formation of the natural elements

- Distribution of the physical structures of the city

- Road network

- Building density and height

- Activity concentration in the area

- Location of major nodes in the area

- Proposed development projects

The spatial structure of Wattala shows that above elements have created Spontaneous organic pattern and makes Wattala as a linear city.

There are prospects and constraints in the linear form. Prospects can be easy expansion of infrastructure, generate high land value for the both sides of the road and less threats to the eco sensitive areas. Constraints can be traffic and activity congestion, overcrowding, inaccessibility to land for public facilities, length of development is too long and do not highlight a strong center with distinct landmark.

This development plan targets to minimize the negative impacts of the linear spatial form by taking advantages of the potentials. 


\section{Strategic Directions}

1. Strengthening Wattala as the multiple business corridor of the region

2. Creating a sustainably developed, people friendly transport infrastructure network

3. Network of accessible parks which promote recreation and economic development mixed with green and blue

4. Enhancing ecologically adopted, zero waste, flood resilience city with green infrastructure

5. Provision of adequate, safe, healthy and comfortable housing for all citizens
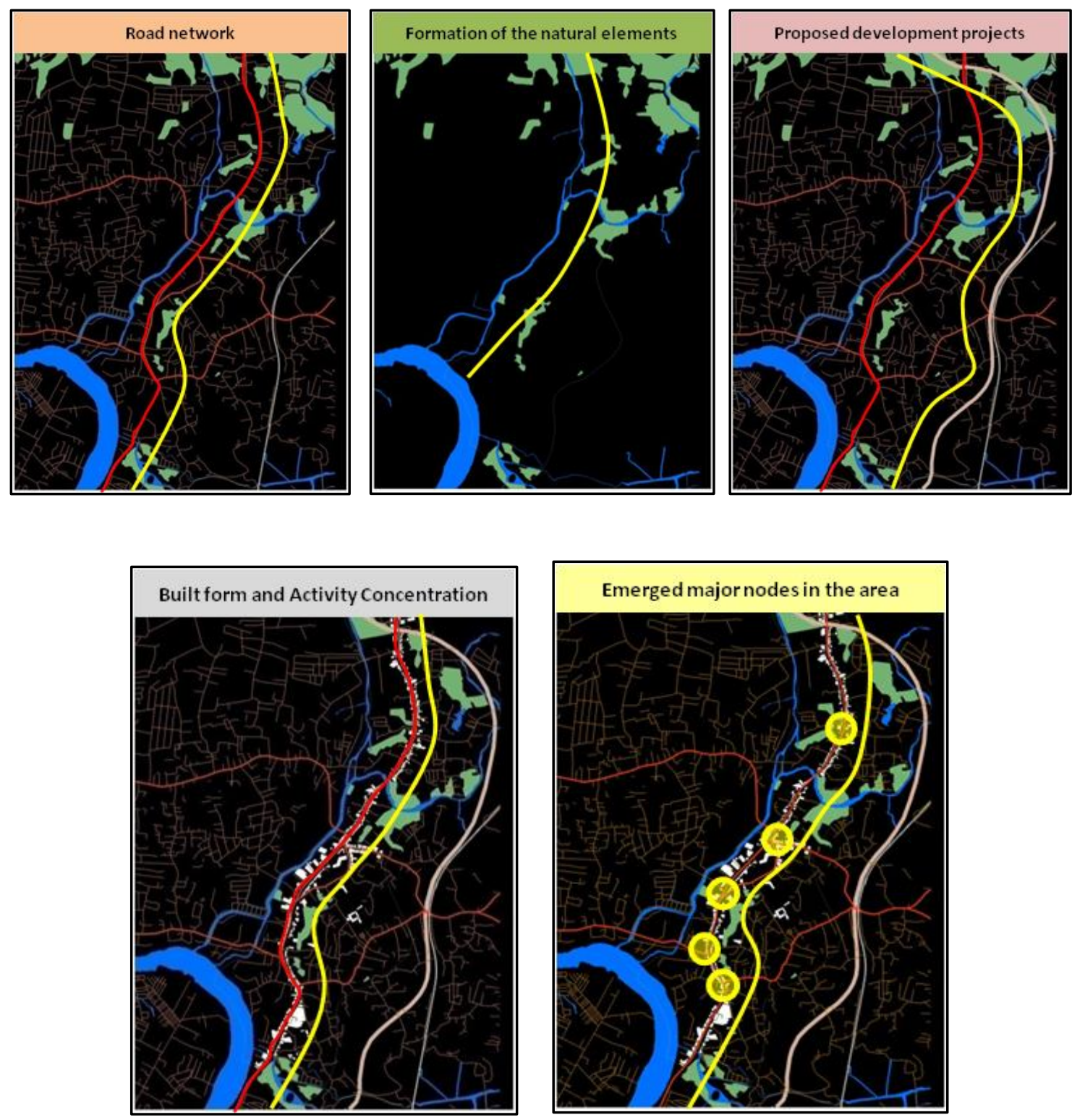

Figure 23: Existing Systems, Patterns and Network 


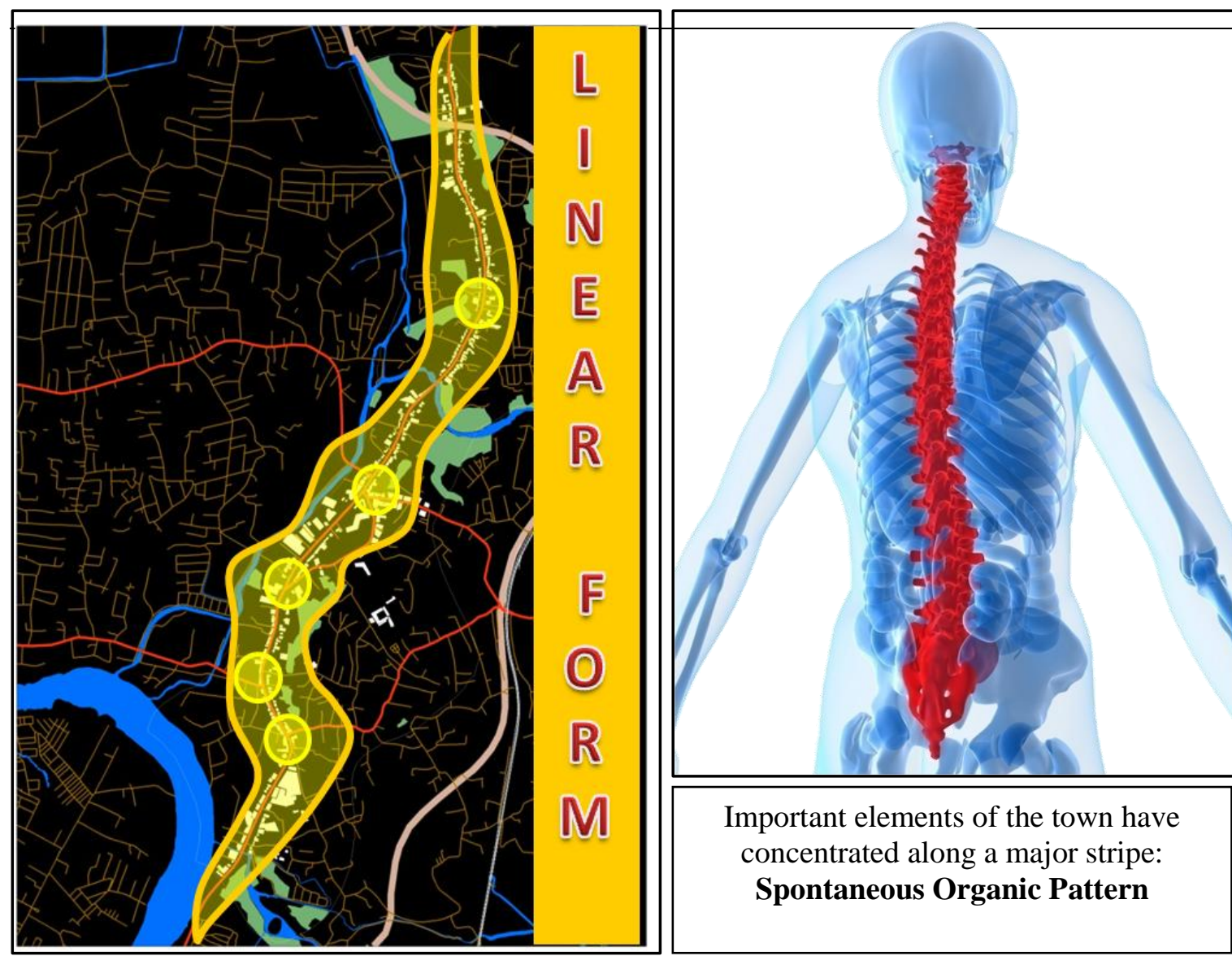

Figure 24: Proposed Spatial Form of Wattala

\section{Strategies, Principles and Actions}

Strategy 1: Strengthening Wattala as the multiple business corridor of the region

\section{Principles}

- Congestion free city; More city space to people; Great safe pedestrian environments

\section{Action}

- Creating a one way vehicular movement plan; Establishing functional road hierarchy; Creating healthy pedestrian environment

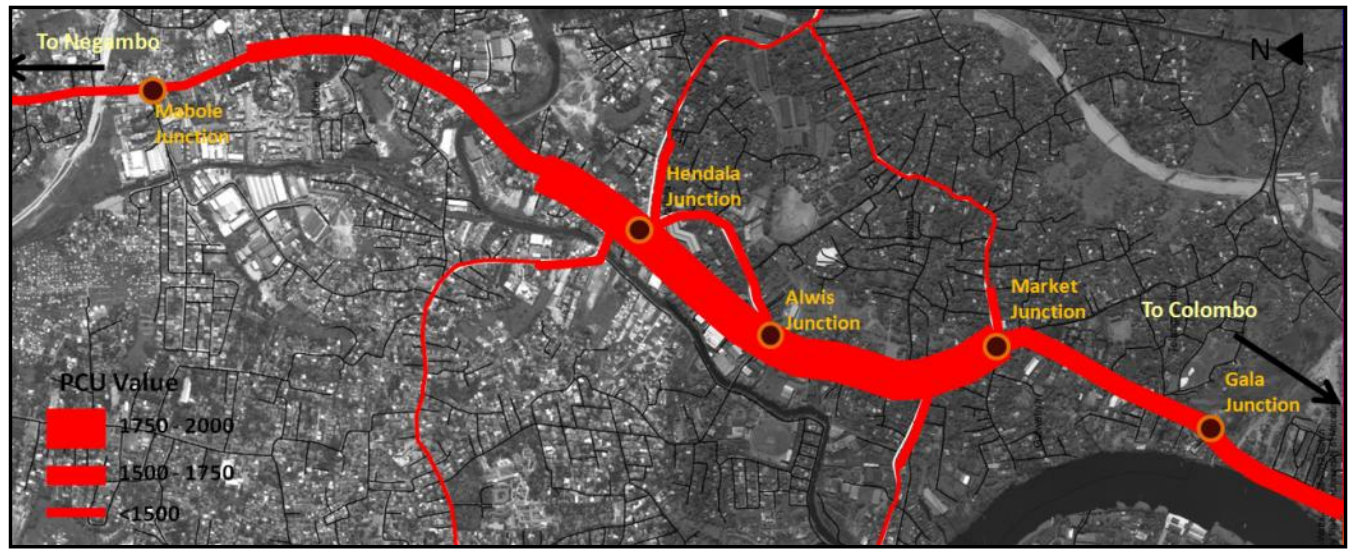

Figure 25: Proposed Multiple Business Corridor of the Region 


\section{Strategy 3:}

Network of accessible parks which promote recreation and economic development mixed with green and blue

\section{Principles}

- Green city concept

\section{Actions}

- Multi entertainment canal park

- River corridor development

- Public park in front of flood retention pond

- Green corridor development
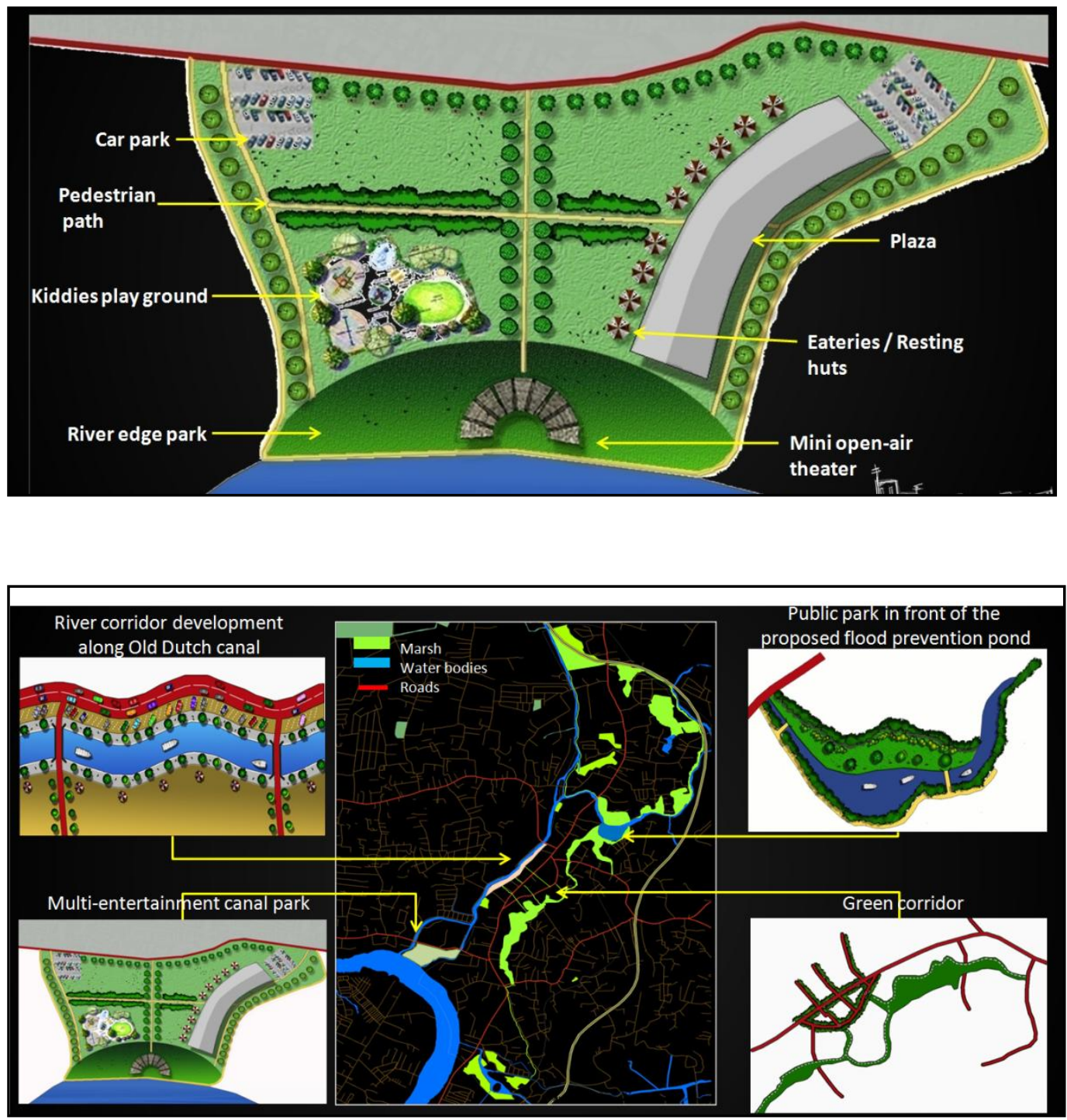

Figure 26: Proposed Corridor Development and Flood Management 
PROJECT TEAM - LEVEL IV STUDENTS - 2008/2012 BATCH

$\begin{array}{ll}\text { Fernando W.R.N. } & \text { Lakmali W.P.D. } \\ \text { Ariyatillake M.D.J.S. } & \text { Liyanage N.V.R. } \\ \text { Bandara H.R.L. } & \text { Madhangani K.G.B. } \\ \text { Bandara P.K.B.D.B. } & \text { Nillegoda N.N.M.L.N.K. } \\ \text { BarthelotT K.F.K.S. } & \text { Pathiranage K.P.N.D. } \\ \text { Buddika W.M.H. } & \text { Perera J.K.H.H. } \\ \text { Dasanayaka W.D.U.A. } & \text { Perera W.P.U.K. } \\ \text { De Gunawardane C.K.A. } & \text { Piyumalie K.G.Y. } \\ \text { Devasanjeev P. } & \text { Prathapasinghe S. } \\ \text { Eranathi W.M.I. } & \text { Priyadarshani U.H.K. } \\ \text { Gangabada L.P. } & \text { Rajapaksha R.P.D.N.N. } \\ \text { Herath H.M.V.K. } & \text { Rupasingha R.P.S.M. } \\ \text { Jayawardana P.D.C.J. } & \text { Salgado M.C.A. } \\ \text { Jayawardana W.M.D.K. } & \text { Sanjeewani H.R.S. } \\ \text { Kabilda K.M. } & \text { Selvaragitha S. } \\ \text { Kanchani K.A. } & \text { Senanayake D.L. } \\ \text { Kumari M.A.W.H. } & \text { Thasan S. } \\ \text { Kumarari W.K.C.C. } & \text { Udugama U.G.S.T. } \\ \text { Vithanage N.L. } & \end{array}$

\section{PROJECT COORDINATORS}

- Prof. PKS Mahanama

- Plnr. AL Susantha

- Shalini Mariyathas

- Gayani Ranasinghe

- Kanishka Guluwitta

- Prathibani Bandusena 